\title{
Diet of the Antillean manatee (Trichechus manatus manatus) in Belize, Central America
}

\author{
AARIN CONRAD ALLEN ${ }^{1,2}$, CATHY A. BECK ${ }^{3}$, ROBERT K. BONDE ${ }^{3}$, JAMES A. POWELL ${ }^{2}$ \\ AND NICOLE AUIL GOMEZ ${ }^{4}$ \\ ${ }^{1}$ Halmos College of Natural Sciences and Oceanography, Nova Southeastern University, 8000 N. Ocean Drive, Dania Beach, FL \\ 33004, USA, ${ }^{2}$ Sea to Shore Alliance, 4411 Bee Ridge Road, \#490, Sarasota, FL 34233, USA, ${ }^{3}$ Sirenia Project, Wetland and Aquatic \\ Research Center, U.S. Geological Survey, 7920 NW 71st Street, Gainesville, FL 32653, USA, ${ }^{4}$ Wildlife Conservation Society, P.O. Box \\ 768, Belize City, Belize
}

\begin{abstract}
Belize contains important habitat for Antillean manatees (Trichechus manatus manatus) and provides refuge for the highest known population density of this subspecies. As these animals face impending threats, knowledge of their dietary habits can be used to interpret resource utilization. The contents of 13 mouth, six digestive tract (stomach, duodenum and colon) and 124 faecal samples were microscopically examined using a modified point technique detection protocol to identify key plant species consumed by manatees at two important aggregation sites in Belize: Southern Lagoon and the Drowned Cayes. Overall, 15 different items were identified in samples from manatees in Belize. Five species of seagrasses (Halodule wrightii, Thalassia testudinum, Ruppia maritima, Syringodium filiforme and Halophila sp.) made up the highest percentage of items. The red mangrove (Rhizophora mangle) was also identified as an important food item. Algae (Ulva sp., Chara sp., Lyngbya sp.) and invertebrates (sponges and diatoms) were also consumed. Variation in the percentage of seagrasses, other vascular plants and algae consumption was analysed as a 4-factor analysis of variance (ANOVA) with main effects and interactions for locality, sex, size classification and season. While sex and season did not influence diet composition, differences for locality and size classification were observed. These results suggest that analysis of diet composition of Antillean manatees may help to determine critical habitat and use of associated food resources which, in turn, can be used to aid conservation efforts in Belize.
\end{abstract}

Keywords: feeding ecology, dietary habits, microhistological analysis, herbivory, seagrass

Submitted 19 August 2016; accepted 31 January 2017; first published online 3 April 2017

\section{INTRODUCTION}

Sirenians are known to consume large quantities of vegetation (Bengtson, 1981, 1983; Best, 1981; Marsh et al., 1982; Hurst \& Beck, 1988). The large-scale grazing habit of these marine mammals is thought to have a positive impact on species biodiversity in seagrass beds (Packard, 1984) and a positive effect on the structure and dynamics of these communities (Aragones \& Marsh, 2000). Knowledge of the diet requirements of sirenians is important for protecting the habitats in which these endangered species reside.

The Antillean manatee (Trichechus manatus manatus), a subspecies of the West Indian manatee (Trichechus manatus), occupies shallow coastal waters surrounding many islands throughout the central Caribbean and also shallow waters adjacent to mainland areas from the Yucatan Peninsula of Mexico south to Alagoas State, Brazil. Manatee numbers within this range are relatively low despite their widespread distribution and suitable habitat to support a larger population (Rathbun et al., 1983; Reynolds et al., 1995; Perez, 2005). There is, however, an estimated population of 1000 manatees within

Corresponding author:

A.C. Allen

Email: aa1429@nova.edu
Belize (Auil Gomez, 2011), and the coastal waters adjacent to Belize are recognized as a critical habitat for the subspecies' continued survival (Quintana-Rizzo \& Reynolds, 2007). A Manatee Recovery Plan has been enacted by the Belizean government to protect the manatee population (Auil, 1998), but the most recent population trends suggest a decline in what was previously thought to be a stable population (Auil, 2004). Because of declining numbers and low genetic variation in Antillean manatee populations (Hunter et al., 2012), conservation of these manatees is a priority.

Belize contains favourable manatee habitat: $386 \mathrm{~km}$ of coastline along with several rivers, tidal lagoons, barrier islands (cayes) to the east, and mangrove lagoons bordering the Mesoamerican Barrier Reef. Recent surveys indicated that manatees were most numerous in the region from Chetumal Bay in the north to Placencia Lagoon in the south and east to the cayes off Belize City (Morales-Vela et al., 2000; Auil, 2004; Edwards et al., 2014). These areas are lined with seagrass beds extending from the shoreline to the outerlying cayes and islands, a coastal system of lagoons and bays that connect with the Caribbean (CZMAI, 2014), as well as networks of freshwater rivers that provide manatees with access to drinking water sites.

Numerous studies have focused on the types of food that sirenians consume in the wild (Best, 1981; Marsh et al., 1982; Gallivan \& Best, 1986; Mignucci-Giannoni \& Beck, 
1998; Lanyon \& Sanson, 2006; Castelblanco-Martinez et al., 2009). Several plant species have been documented as occurring within the digestive tract of Florida manatees (T. manatus latirostris) (Best, 1981; Ledder, 1986; Hurst \& Beck, 1988), Antillean manatees (Mignucci-Giannoni \& Beck, 1998; Castelblanco-Martinez et al., 2009; NavarroMartinez et al., 2014), Amazonian manatees (T. inunguis) (Colares \& Colares, 2002; Guterres-Pazin et al., 2014) and the dugong (Dugong dugon) (Heinsohn \& Birch, 1972; Lipkin, 1976; Marsh et al., 1982). Best (1981) conducted the first comprehensive review on the feeding behaviour, digestive physiology, consumption and diet of sirenians in wild and captive settings. A study focused on the diet of the Amazonian manatee identified a total of 24 different macrophytes from digestive tract and faecal samples with higher diversity in types of vegetation consumed during the dry season; manatees appeared to be more selective on what they consumed during the wet season (Colares \& Colares, 2002; Guterres-Pazin et al., 2014). Some of the most comprehensive diet data for manatees are specific to the Florida manatees (Bengtson, 1983; Hurst \& Beck, 1988; Ames et al., 1996; Alves-Stanley et al., 2010). In Florida, manatees are known to consume over 60 different species of plants (Hartman, 1979; Bengtson, 1981, 1983; Best, 1981; Hurst \& Beck, 1988) of varying nutritional value (Siegal-Willott et al., 2010). Antillean manatees in Puerto Rico were reported to consume 10 different species of vegetation (MignucciGiannoni \& Beck, 1998). A wide range of estimates exists with regard to the amount of food manatees consume in a given day, from 9 to $80 \mathrm{~kg}$ (Severin, 1955; Crandall, 1964; Pinto de Silveira, 1975; Hartman, 1979; Best, 1981; Lomolino \& Ewel, 1984), and between 4-9\% (Bengtson, 1983) to $10-15 \%$ of their body weight per day (Reep \& Bonde, 2006). The quantity of vegetation eaten is dependent on the animals' size, activity level, nutritional value of the food source, metabolic requirements and perhaps reproductive condition. Consumption is also influenced by the availability of plants, which is dependent on a broad suite of environmental conditions.

Manatees select habitat based on the availability of food and proximity to freshwater resources (Hartman, 1979; Packard \& Wetterqvist, 1986; O'Shea \& Kochman, 1990; Gannon et al., 2007). In order to meet their metabolic requirements, manatees must consume large quantities of vegetation on a daily basis (Smith, 1993). Seagrasses are an important food source for West Indian manatees and unfortunately, there have been documented declines in seagrass productivity (biomass) and biodiversity in many areas (Short \& Wyllie-Echeverria, 1996; Duarte, 2002; Orth et al., 2006; Waycott et al., 2009), including Belize (Short et al., 2006; Parham-Garbutt, 2015). Manatees also face habitat loss within many parts of their range which limits the resources necessary for their survival (Smith, 1993).

Several methods have been used to study the diet of herbivores, including direct observation and examination of ingesta and faecal samples using microhistological analysis employing a microscope point technique (Hurst \& Beck, 1988). Microhistological analysis is a favoured method for the identification of ingesta and faecal samples collected from terrestrial herbivores (Holechek \& Vavra, 1981) and has been employed also to study the diets of aquatic herbivores (Owen, 1975; Black et al., 1994; Carriere et al., 1999; Castelblanco-Martinez et al., 2009; Flores-Cascante et al.,
2013) including sirenians (Channels \& Morrissey, 1981; Hurst \& Beck, 1988; Mignucci-Giannoni \& Beck, 1998). This modified microscope point technique has proved to be an effective, yet inexpensive, method to gather information on diets of herbivores, and the methodology outlined by Hurst \& Beck (1988) was followed for this study.

Here we provide the first in-depth information on manatee diet in Belize. Two high-use areas of Belize were compared to determine locational differences in manatee diet and to determine which habitats are likely to provide important resources for manatees. A better understanding of how Antillean manatees utilize these different areas will be necessary to develop and implement effect management plans for this endangered species.

\section{MATERIALS AND METHODS}

\section{Subjects and sampling areas}

Samples were obtained from manatees temporarily retained for telemetry studies at two locations in Belize (Figure 1): Southern Lagoon $\left(17^{\circ} 12^{\prime} 40^{\prime \prime} \mathrm{N} \quad 88^{\circ} 20^{\prime} 17^{\prime \prime} \mathrm{W}\right)$ near Gales Point, Belize District from 1997-2008, 2010 and 2012, and the Drowned Cayes $\left(17^{\circ} 29^{\prime} 25^{\prime \prime} \mathrm{N} 88^{\circ} 08^{\prime} 10^{\prime \prime} \mathrm{W}\right)$ off Belize City, Belize District from 2004-2007, 2012 and 2013. Ingesta also were obtained at necropsy from manatee carcasses collected near Belize City in 1999, 2002, 2003, 2008 and 2013 .

\section{Collection methods}

From 1997-2013, health assessments were conducted in Belize as part of a tagging study involving the capture and release of wild manatees. Individual manatees were net captured by an experienced crew from Florida and Belize, and pulled onto land or onto the deck of a specialized boat for a detailed physical examination (Bonde et al., 2012; Wong et al., 2012). Routine measurements and biological samples were collected from 137 manatees, including 13 mouth and

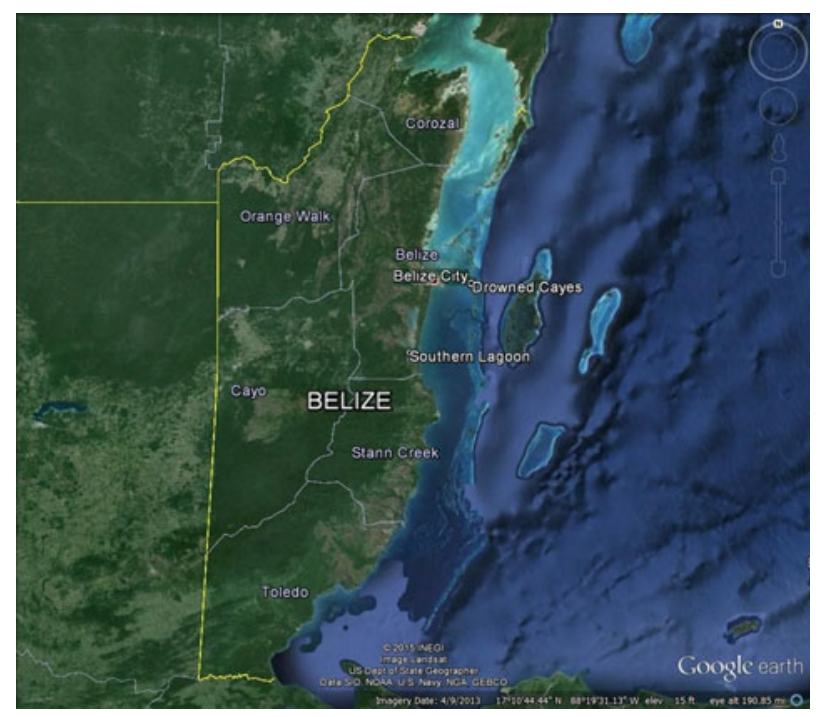

Fig. 1. District map of Belize showing areas of sample collection in the Drowned Cayes and Southern Lagoon, and carcasses collected near Belize City. 
124 faecal content. Additional ingesta samples from the stomach (4), duodenum (1) and colon (1) were obtained from six manatee carcasses (collected by the Belize Marine Mammal Stranding Network), yielding a total of 143 samples for analysis. In total, 111 samples were taken from animals captured in Southern Lagoon and 32 from animals captured in the Drowned Cayes. All samples were preserved in $70 \% \mathrm{EtOH}$ upon collection and stored until ready for examination.

\section{Microhistological analysis}

Samples were not processed to achieve a uniform size as has been done in other diet studies, since a large fragment size was preferred to enable easier identification. Prior to examination, each sample was rinsed with tap water over a 30-mesh $(0.52 \mathrm{~mm})$ screen to remove sand, dirt and other fine particulate matter that might obscure microscopic observation of plant cellular structures. After rinsing, a subsample of the digesta was placed on a $2 \times 3$ inch glass slide to which several drops of Hertwig's solution was added. The slide was then held over an alcohol flame to facilitate the clearing of pigments from the plant cells, allowing for easier viewing of cellular structures. After clearing, the subsample was divided onto five additional $2 \times 3$ inch glass slides for microhistological examination.

During microscopic observation, each slide was first observed at $40 \times$ for the purpose of scanning the contents. Samples were then observed at $100 \times$ and analysed for content. Each slide was analysed through the microscope by identifying five points visible in an eyepiece micrometer grid along a prescribed transect sequence at 20 different coordinates on the stage; observations were recorded at each coordinate. This allowed for 100 different points of identification on each slide and was repeated five times for each sample. Using this modified microscope point technique developed by Owen (1975) and Holechek et al. (1982a, b), and detailed in Hurst \& Beck (1988) and Beck \& Clementz (2012), 500 points in each sample were identified using microhistological characters of visible plant fragments. The frequency of items was identified for the overall diet of manatees in Belize by recording the number of times each item was found in a sample, divided by the total number of samples studied.

To assist with identification, plant fragments were compared with reference voucher slides and photomicrographs available at the USGS Sirenia Project laboratory, along with illustrations from Hurst \& Beck (1988) that describe leaf, stem, flower, root and rhizome fragments of over 100 plant species catalogued for the study of manatee diet through microhistological examination. Some species of algae were identified using field guides (Littler et al., 1989; Littler \& Littler, 2008) and outside expert analysis. Photomicrographs of some algal fragments and intact samples were sent to Dr Donald W. Ott at the University of Akron for identification by election microscopy. Photographs were obtained of some ingested items for subsequent confirmation of identification.

\section{Data analysis}

Samples from manatees in Belize were divided into groups and evaluated based on location, sex, size classification and season. Size classifications for manatees were based on records maintained for 280 manatee health assessments conducted in
Belize, and defined as follows: calves $(<200 \mathrm{~cm})$, juveniles $(>200-<245 \mathrm{~cm})$ and adults $(>245 \mathrm{~cm})$. Per cent frequency of species observed was determined by adding the total count of each species type detected in the samples, divided by the total number of samples analysed for each group, and then divided by 500 (see Microhistological analysis), i.e. $P_{F}=\frac{n_{s p}}{500}$. Diet composition was also described through per cent occurrence of samples analysed across four categories: seagrasses, other vascular plant material, algae and invertebrates. Variation in per cent occurrence of seagrasses, other vascular plant material, and algae was further analysed statistically as a factorial analysis of variance (ANOVA) with main effects and interactions for locality, sex, size classification and season. Prior to analysis, the data were transformed to ranks to adjust for the non-normal distribution of percentages. All statistical analyses were carried out using the SAS PROC GLM utility (SAS Institute Inc., 2013).

\section{RESULTS}

Microhistological analysis revealed the contents of each sample by identifying plant fragments through microscopic investigation. The fragment sizes in mouth and stomach samples were larger than those found in faecal samples. Mouth samples contained almost complete, intact pieces of plant material, thus facilitating identification. As samples progressed further along the digestive tract, advancing from the stomach to distal colon, sample integrity and the ease of identifying fragments decreased due to digestive processes. When possible, ingesta were identified to genus as well as fragment component (e.g. leaf, stem, rhizome), then categories of species were summarized based on their occurrence within the samples.

\section{Components of the manatee diet in Belize}

The number of unique species identified in each sample ranged from 1 to 6 . Mouth samples consisted of $1-2$ species of seagrass, whereas 1-4 species were identified in GI-tract samples, and 1-6 different species were identified in faecal samples. Most samples, however, contained fragments from more than one diet category. Of the 143 samples, mixed seagrass rhizome was found in $129(90.21 \%)$ samples. The seagrass Halodule wrightii was the second most frequently detected dietary item and occurred in 114 (79.72\%) samples. In samples with mixed seagrass rhizome, the exact species of seagrass was not always discernible. Overall, 15 different items were observed in samples in addition to the highest ranked component of seagrass rhizome (Table 1). The relative occurrence of the dietary items in all samples $(\mathrm{N}=143)$ by category is summarized in Table 2.

All 143 samples were examined to identify per cent occurrence relative to 500 identification points in each sample (Table 2) and to classify the average composite dietary make-up of each specimen. Identities were type categorized as 'seagrasses' (Halodule wrightii, Thalassia testudinum, Ruppia maritima, Syringodium filiforme, Halophila sp. and seagrass rhizome), 'vascular plant(s) - other' (e.g. Rhizophora mangle and unidentified vascular plant), 'algae' (e.g. Ulva sp., unidentified filamentous algae), or 'invertebrates' (e.g. unknown poriferan, unknown invertebrate). Seagrass leaf and/or rhizome had the highest average per 
Table 1. Per cent frequency of items identified in manatee ingesta.

\begin{tabular}{lrc}
\hline Plant type & $n$ & Per cent (\%) \\
\hline Seagrasses & & \\
$\quad$ Mixed rhizome & 129 & 90.21 \\
$\quad$ Halodule wrightii & 114 & 79.72 \\
Thalassia testudinum & 54 & 37.76 \\
Ruppia maritima & 52 & 36.36 \\
Syringodium filiforme & 4 & 2.80 \\
Halophila sp. & 2 & 1.40 \\
Vascular plants - other & & \\
$\quad$ Rhizophora mangle & 76 & 53.15 \\
$\quad$ Unknown vascular plant(s) & 2 & 1.40 \\
Algae & & \\
Unknown filamentous algae & 53 & 37.06 \\
Ulva sp. & 9 & 6.29 \\
Chara sp. & 4 & 2.80 \\
Lyngbia sp. & 2 & 1.40 \\
$\quad$ Unknown calcified algae & 1 & 0.70 \\
Invertebrates & & \\
Sponge & 19 & 13.29 \\
Diatoms & 5 & 3.50 \\
Unknown invertebrates & 4 & 2.80 \\
\hline
\end{tabular}

Table 2. Per cent occurrence of diet items in 143 Belize manatee samples, summarized by plant category.

\begin{tabular}{lrlrlllr}
\hline Plant type & Mean & Min. & Max. & SD & Var & SE & CV \\
\hline Seagrasses & 81.06 & 0 & 100 & 21.34 & 455.31 & 1.78 & 26.32 \\
Vascular & 6.72 & 0 & 84 & 11.99 & 143.84 & 1 & 178.54 \\
$\quad$ plants - & & & & & & & \\
$\quad$ other & & & & & & & \\
Algae & 2.48 & 0 & 33.80 & 5.32 & 28.31 & 0.45 & 214.22 \\
Invertebrates & 1.60 & 0 & 33.20 & 5.13 & 26.32 & 0.43 & 319.79 \\
\hline
\end{tabular}

cent occurrence in the diet (Table 2). In several samples, there were some fragments that were unidentifiable at the time of observation. Since it was not possible to classify these fragments, they were disregarded for analytical purposes.

\section{Manatee diet by location}

Diet contents were analysed from samples collected in two locations (Appendix A). Seagrass rhizome was the predominant ingested dietary item at both Southern Lagoon and the Drowned Cayes $(\mathrm{N}=111,90.09 \%$ frequency in Southern Lagoon; $\mathrm{N}=32,90.63 \%$ in the Drowned Cayes). Halodule wrightii was the most frequently identified component from both Southern Lagoon $(\mathrm{N}=85,76.58 \%)$ and the Drowned Cayes $(\mathrm{N}=29,90.63 \%)$. Rhizophora mangle and Ruppia maritima also were common in samples from Southern Lagoon, as were Thalassia testudinum and Rhizophora mangle in samples from the Drowned Cayes. Per cent frequency of other dietary components by location is provided in Appendix A.

The average per cent occurrence from samples obtained in Southern Lagoon and the Drowned Cayes indicated that seagrass was a primary component in specimens from Southern Lagoon: $83.14 \%(\mathrm{SD}=20.87)$ and the Drowned Cayes: $73.18 \%(\mathrm{SD}=21.89)$. Per cent occurrence to classify the composite dietary sample by location is provided in Appendix B. In a reduced three-factor ANOVA (to account for no significant difference by sex), locality had a significant effect on seagrass consumption $(P=0.03)$ due to a higher estimated mean in Southern Lagoon $(83.5 \pm 2.12)$ compared with the Drowned Cayes $(70.5 \pm 4.58)$. However, per cent consumption of both mangrove and algae were significantly higher $(P=0.03)$ in the Drowned Cayes (mangrove: $14.7 \pm 2.35$, algae $4.6 \pm 1.00)$ when compared with Southern Lagoon (mangrove: $5.4 \pm 1.08$, algae $1.5 \pm 0.46$ ).

\section{Manatee diet by sex}

Samples were collected from 65 males and 76 females. Samples from both male and female manatees contained primarily seagrass rhizome and leaf material, with an average of $83.41 \%$ $(\mathrm{SD}=19.05)$ seagrass in males and an average of $78.97 \%$ $(\mathrm{SD}=23.15)$ seagrass in females. There was no significant difference in diet composition by sex $(P>0.09)$. Per cent frequency of other dietary components by sex is provided in Appendix C; per cent occurrence to classify the composite dietary sample by location is provided in Appendix D.

\section{Manatee diet by size classification}

For all size classifications, diets were very similar with mixed seagrass rhizome, Halodule wrightii, and Rhizophora mangle (red mangrove) occurring most frequently in both locations. Per cent frequency of other dietary components compared between size classifications is provided in Appendix E.

Size classifications also were analysed to examine per cent occurrence between each plant type. Seagrasses were again the type seen most frequently. Samples from manatee calves contained a mean $85.02 \%$ seagrass $(S D=17.86)$, juvenile manatee samples averaged $79.26 \%$ seagrass $(S D=25.24)$, and adult samples consisted of a mean of $82.23 \%$ seagrass $(\mathrm{SD}=20.20)$. Per cent occurrence to classify the composite dietary sample by location is provided in Appendix F. Per cent algae consumption was also significantly affected by size classification $(P=0.04)$ due to a higher estimated mean for manatees $>245 \mathrm{~cm}(3.8 \pm 0.65)$ compared with manatees $\leq 245 \mathrm{~cm} \mathrm{(2.3 \pm 0.89)}$.

\section{Manatee diet by season}

Belize experiences a wet season from June to November, with peak rainfall in July and August, and a dry season from December to May. Samples from the wet $(\mathrm{N}=89)$ and dry season $(\mathrm{N}=52)$ contained rhizome in the majority of samples (wet $=82,92.13 \%$, dry $=47,90.38 \%$ ), followed by Halodule wrightii (wet $=75,84.27 \%$, dry $=39,75.00 \%$ ). Wet and dry seasons were compared by per cent occurrence of each type. Seagrass occurred most frequently in samples from both seasons. Wet season samples contained $79.86 \%$ seagrass, while samples from the dry season contained $83.00 \%$ seagrass $(\mathrm{SD}=20.31)$. There was no significant difference in diet composition by season $(P>0.30)$. Per cent frequency of other dietary components by sex is provided in Appendix $\mathrm{G}$; per cent occurrence to classify the composite dietary sample by location is provided in Appendix $\mathrm{H}$.

\section{DISCUSSIDN}

The items present in diet samples from this study in Belize have been previously reported for manatees in other locations 
throughout the Atlantic and broader Caribbean regions (Best, 1981; Ledder, 1986; Hurst \& Beck, 1988; Mignucci-Giannoni \& Beck, 1998; Borges et al., 2008; Castelblanco-Martinez et al., 2009). The findings reported here are similar to those from studies in nearby areas, i.e. Mexico and Belize (Castelblanco-Martinez et al., 2009; Flores-Cascante et al., 2013), and are comparable to studies conducted in similar habitats around Puerto Rico (Mignucci-Giannoni \& Beck, 1998). Manatees feed predominantly on seagrasses, as determined in previous studies, and the seagrasses consumed by manatees in this study are in similar order of importance as reported by Mignucci-Giannoni \& Beck (1998), CastelblancoMartinez et al. (2009) and Flores-Cascante et al. (2013). The findings are also congruent with results from stable isotope analysis of manatee tissues from Belize (Alves-Stanley et al., 2010). Other vascular plant material (mangrove specifically) made up a considerable portion of the identified diet items. Similar findings have been reported for manatees in Puerto Rico, Mexico and Belize (Mignucci-Giannoni \& Beck, 1998; Castelblanco-Martinez et al., 2009; Flores-Cascante et al., 2013). Fragments of Ulva sp., Chara sp., and Lyngbya sp. were identified, but unidentified algal remains were a frequent occurrence. Of the three discernible algal species, two have been reported from Antillean manatees in other locations: Ulva sp. in Puerto Rico (Mignucci-Giannoni \& Beck, 1998) and Chara sp. in Mexico (Castelblanco-Martinez et al., 2009). All three algal species have been observed in content samples from Florida (Hurst \& Beck, 1988). Manatee diet samples in Belize also contained small amounts of invertebrates, primarily identified as an unknown poriferan.

Invertebrates often occur in close association with seagrasses and incidental ingestion is likely (Hartman, 1979; Best, 1981; Ledder, 1986; Hurst \& Beck, 1988; Courbis \& Worthy, 2003), although manatees and dugongs are known to be omnivorous when resources are limited (Lipkin, 1976; Powell, 1978; Preen, 1995a). Sand grains, detrital material and microalgae were observed in the samples we examined and were probably ingested incidentally. Mouth and stomach samples were the least digested and contained the most identifiable fragments. Manatees have a very long digestive tract and a 4-7 day passage time (Larkin et al., 2007). Faecal samples, which are more fully digested, were the greatest challenge for identification. Faecal samples therefore may not precisely reflect individual feeding habits, since some components of the diet may no longer be identifiable. As expected, faecal samples contained a higher amount of unknown or unidentifiable points during examination and contained a higher percentage of rhizomes which is not as easily degraded through digestion. Because some portions of the samples contained unidentified fragments, the complete composition of each sample could not be attained. For example, not all algae were identifiable, but filamentous algae were more often observed in our Belize samples.

\section{Diet differences between locations}

Seagrass was found in more samples and in higher percentages in samples collected in Southern Lagoon $(P=0.03)$; algae and mangrove made up a larger proportion of those samples from the Drowned Cayes $(P=0.03)$. Likewise, Alves-Stanley et al. (2010) observed a difference in $\delta^{13} \mathrm{C}$ and $\delta^{15} \mathrm{~N}$ values between manatees sampled in the Drowned Cayes and Southern Lagoon. Observed variation in ingested food items between manatees in Southern Lagoon and Drowned Cayes may be attributed to environmental differences between the two sites.

As manatees are able to move between fresh, salt and brackish waters, they have been documented to make use of dominant plant types in each type of environment. Differences in diet between the two locations in Belize illustrated only slight dietary differences. By comparison, manatee diets in Florida are highly variable by region (Alves-Stanley et al., 2010). Florida manatee diets often contain the same seagrass types as manatees in the Caribbean (Best, 1981; Ledder, 1986; Hurst \& Beck, 1988; Mignucci-Giannoni \& Beck, 1998; Castelblanco-Martinez et al., 2009; Flores-Cascante et al., 2013), but also contain several additional genera of algae and freshwater plants not identified in these Belize samples (e.g. Chara, Gracilaria, Hydrilla, Myriophyllum, Najas, Vallisneria). Antillean manatee diet samples in Brazil were comprised of 21 different types of algae, seagrasses and invertebrates, but predominantly contained rhodophytes (Borges et al., 2008), while Amazonian manatees consumed at least 24 different plant species within the central Amazon (Borges et al., 2008).

The presence of mangrove fragments detected in the samples obtained from manatees in the Drowned Cayes (59\%) was higher than those for individuals sampled from Southern Lagoon (51\%). In the Drowned Cayes, manatees were usually associated with, and captured near, mangrove forest islands located offshore of the mainland. Mangrove islands provide shelter for manatees in these open-water marine environments, and additionally, mangrove leaves store fresh water (Odum \& McIvor, 1990). The higher detection of mangrove ingesta in the manatees from the Drowned Cayes may indicate, by association, the use of mangrove forage to supplement their need for fresh water. The fresh water available in this vascular plant may enable manatees to spend longer periods of time in marine environments.

\section{Diet differences between sexes and sizes}

There were no significant differences observed in diet preferences between male and female manatees in Belize. This finding is consistent with a previous study carried out in Mexico (Castelblanco-Martinez et al., 2009). No other known published account has demonstrated a significant difference in diet between the sexes. Of the 76 females in our study, four were sampled when lactating. Pregnant or lactating females may have additional nutritional needs, but no obvious difference in diet composition of these females was discernible.

No difference in manatee diet between size classifications was detected for seagrass or [other] vascular plant consumption, but adult manatees $(>245 \mathrm{~cm})$ consumed a statistically greater proportion of algae: adult mean $3.8 \pm 0.65$, juveniles $2.3 \pm 0.89(P=0.04)$. No previous studies have analysed the relationship between manatees' size (length) and diet. Influencing factors may be a result of larger manatees consuming a greater amount of food and/or the duration of time spent feeding.

\section{Diet differences between seasons}

Manatees in Belize have been observed to utilize different habitat types in the wet and dry seasons (Morales-Vela et al., 2000; Self-Sullivan et al., 2003; Auil, 2004; Auil et al., 2007), however, no statistical differences in the diet samples 
were observed in this study. Similar to Belize, no seasonal differences in diet were observed nearby in Chetumal Bay, Mexico (Castelblanco-Martinez et al., 2009), and no seasonal differences in diet have been observed in the dugong as well (Preen, 1995b). In the Amazon, manatees have been observed to be more selective during the rainy season, but fed on a more diverse number of plants during the dry season (Colares \& Colares, 2002; Guterres-Pazin et al., 2014). Although seasonal habitat use may change within Belize, the uniform similarity of food plants available for consumption year-round may account for the lack of seasonal diet differences reported in this study.

Alves-Stanley et al. (2010) used stable-isotopes to infer seasonal changes in manatee diet and observed a difference in $\delta^{13} \mathrm{C}$ and $\delta^{15} \mathrm{~N}$ values between manatees sampled in the Drowned Cayes and Southern Lagoon. Rather than attribute this simply to environmental differences between the two sites, this could be a result of changes in manatee resource selection (food or habitat use), and/or seasonal variability in the stable isotope ratios of vegetation. Manatees in Belize have been known to make seasonal changes in habitat use (Morales-Vela et al., 2000; Auil et al., 2007) and have been documented moving between the two sampling sites within the same day (RKB, JAP, personal observation). As most of the specimens examined in this study were faecal samples, a precise snapshot of manatee diet differences cannot be assumed due to a manatees' long gut transit time.

\section{Conclusions and future recommendations}

Belize is a central location for the Antillean manatee population (O'Shea \& Salisbury, 1991) and provides important habitat for the long-term survival of the subspecies (Quintana-Rizzo \& Reynolds, 2007; Auil Gomez, 2011). Manatee populations can be used to assess the health of marine ecosystems as they are a sentinel species for habitat quality (Bonde et al., 2004). In Belize, manatees face an increasing threat from anthropogenic and natural causes of mortality including boat strikes and habitat alteration from construction and contaminated effluents (Auil Gomez, 2011). An understanding of the types, species, areas and feeding preferences of manatees is helpful for developing conservation and habitat protection plans for manatees.

This study found that the seagrasses Halodule wrightii, Thalassia testudinum and Ruppia maritima are the predominant food items consumed by manatees in Belize. Red mangrove (Rhizophora mangle) also made up a significant portion of the observed manatee diet. Algae and invertebrates were detected in small quantities. The high frequency of seagrass rhizome and mangrove leaves observed in the faecal samples may be attributed to the indigestibility and toughness of these fragments, and, therefore, the overall proportions may be overrepresented. Further, the amount of rhizome consumed is dependent on the species and substrate. Our findings emphasize the importance for protection and preservation of seagrass and mangrove habitats in Belize to promote a positive outcome for this important regional population of manatees.

\section{ACKNDWLEDGEMENTS}

This research was conducted as part of a Master of Science thesis project of ACA while at Nova Southeastern University. ACA would like to thank his committee members Dr James D. Thomas and Dr Curtis M. Burney of Nova Southeastern University, and CAB and RKB of USGS for their encouragement and support. We appreciate the assistance of the Belize Marine Mammal Stranding Network, in particular Jamal Galves of Sea to Shore Alliance-Belize, and thank the capture team from Gales Point 'Manatee' Village for enabling the collection of the samples used in this study. Additional thanks to Dr Donald W. Ott at the University of Akron for confirmation of diet contents through electron light microscopy. We appreciate the constructive and insightful comments of Dr Tom Frazer, University of Florida, and two anonymous reviewers on earlier versions of this manuscript. This work was conducted under authority granted by the Belize Forestry Department, as well as the U.S. Fish and Wildlife Service research permit MA791721-4 issued to the U.S. Geological Survey Sirenia Project. All sample collection was conducted in accordance with IACUC standards and samples were imported into the USA under valid CITES permits. Any use of trade, firm, or product names is for descriptive purposes only and does not imply endorsement by the U.S. Government.

\section{REFERENCES}

Alves-Stanley C.D., Worthy G.J.A. and Bonde R.K. (2010) Feeding preferences of West Indian manatees in Florida, Belize, and Puerto Rico as indicated by stable isotope analysis. Marine Ecology Progress Series 402, 255-267.

Ames A.L., Van Vleet E.S. and Sackett W.M. (1996) The use of stable carbon isotope analysis for determining the dietary habits of the Florida manatee, Trichechus manatus latirostris. Marine Mammal Science 12, 555-563.

Aragones L.V. and Marsh H.D. (2000) Impact of dugong grazing and turtle cropping on tropical seagrass communities. Pacific Conservation Biology 5, 277-288.

Auil N.E. (1998) Belize Manatee Recovery Plan. UNDP/GEF Coastal Zone Management Project BZE/92/G31. Kingston: Belize/UNEP Caribbean Environment Programme, pp. 1-72.

Auil N.E. (2004) Abundance and distribution trends of the West Indian manatee in the coastal zone of Belize: implications for conservation. MS thesis. Texas A\&M University, College Station, TX, 83 pp.

Auil N.E., Powell J.A., Bonde R.K., Andrewin K. and Galves J. (2007) Belize conservation program, ten year summary. Report to Liz Claiborne Art Ortenberg Foundation. New York, NY: Wildlife Trust.

Auil Gomez N. (2011) The fate of manatees in Belize. In Palomares M.L.D. and Pauly D. (eds) Too precious to drill: the marine diversity of Belize. Fisheries Centre Research Reports 19(6), University of British Columbia, pp. 19-24.

Beck C.A. and Clementz M.T. (2012) Techniques for determining the food habits of Sirenians. In Hines E.M., Reynolds III J., Aragones L.V., Mignucci-Giannoni A.A. and Marmontel M. (eds) Sirenian conservation: issues and strategies in developing countries. Gainesville, FL: University Press of Florida, pp. 126-132.

Bengtson J.L. (1981) Ecology of manatees (Trichechus manatus) in the St. Johns River, Florida. PhD dissertation. University of Minnesota, Duluth, MN, 126 pp.

Bengtson J.L. (1983) Estimating food consumption of free-ranging manatees in Florida. Journal of Wildlife Management 47, 1186-1192.

Best R.C. (1981) Foods and feeding habits of wild and captive Sirenia. Mammal Review 11, 3-29. 
Black J.M., Prop J., Hunter J.M., Woog F., Marshall A.P. and Bowler J.M. (1994) Foraging behavior and energetics of the Hawaiian goose Branta sandvicensis. Wildfowl 45, 65-109.

Bonde R.K., Aguirre A.A. and Powell J.A. (2004) Manatees as sentinels of marine ecosystem health: are they the 2000-pound canaries? EcoHealth 1, 255-262.

Bonde R.K., Garrett A., Berlanger M., Askin N., Tan L. and Wittnich C. (2012) Biomedical health assessments of the Florida manatee in Crystal River - providing opportunities for training during the capture, handling, and processing of this unique aquatic mammal. Journal of Marine Animals and Their Ecology 5, 17-28.

Borges J.C.G., Araujo G.P., Anzolin G.D. and Miranda C.E.G. (2008) Identificacao de itens alimentares constituientes da dieta dos peixesboi marinhos (Trichechus manatus) na regiao Nordeste do Brasil Biotemas 21, 77-81.

Carriere S., Bromley R.G. and Gauthier G. (1999) Comparative spring habitat and food use by two Arctic nesting geese. Wilson Bulletin $111,166-180$.

Castelblanco-Martinez D.N., Morales-Vela B., Hernandez-Arana H.A. and Padilla-Saldivar J.A. (2009) Diet of manatees Trichechus manatus manatus in Chetumal Bay, Mexico. Latin American Journal of Aquatic Mammals 7, 39-46.

Channels P. and Morrissey J. (1981) Technique for the analysis of seagrass genera present in dugong stomachs, including a key to North Queensland seagrasses based on cell details. In Marsh H. (ed.) The Dugong, proceedings of a seminar/workshop held at James Cook University of North Queensland; 8-13 May 1979. St. Lucia Australia, pp. 303-309.

Coastal Zone Management Authority \& Institute (CZMAI) (2014) State of the Belize Coastal Zone report 2003-2013. Belize City: Coastal Zone Management Authority \& Institute.

Colares I.G. and Colares E.P. (2002) Food plants eaten by Amazonian manatees (Trichechus inunguis, Mammalia: Sirenia). Brazilian Archives of Biology and Technology 45, 67-72.

Courbis S.S. and Worthy G.A.J. (2003) Opportunistic carnivory by Florida manatees (Trichechus manatus latirostris). Aquatic Mammals 29, 104-107.

Crandall L.S. (1964) The management of wild animals in captivity. Chicago, ILL: University of Chicago Press, $761 \mathrm{pp}$.

Duarte C.M. (2002) The future of seagrass meadows. Environmental Conservation 29, $192-206$.

Edwards H.H., Stone S.B.P., Hines E.M., Auil Gomez N. and Winning B.E. (2014) Documenting manatee (Trichechus manatus manatus) presence at Turneffe Atoll, Belize, Central America and its conservation significance. Caribbean Journal of Science 48, 71-75.

Flores-Cascante L., Morales-Vela B., Castelblanco-Martinez N., Padilla-Saldivar J. and Auil N. (2013) Diet items of manatee Trichechus manatus manatus in three priority sites for the species in Mexico and Belize. Revista Ciencias Marinas y Costeras 5, 25-36.

Gallivan G.J. and Best R.C. (1986) The influence of feeding and fasting on the metabolic rate and ventilation of the Amazonian manatee (Trichechus inunguis). Physiological Zoology 59, 552-557.

Gannon J.G., Scolardi K.M., Reynolds J.E., Koelsch J.K. and Kessenich T.J. (2007) Habitat selection by manatees in Sarasota Bay, Florida Marine Mammal Science 23, 133-143.

Guterres-Pazin M., Marmontel M., Rosas F.C.W., Pazin V.F.V. and Venticinque E.M. (2014) Feeding ecology of the Amazonian manatee (Trichechus inunguis) in the Mamirauá and Amanã Sustainable Development Reserves, Brazil. Aquatic Mammals 40, 139-149. doi: 10.1578/AM.40.2.2014.139.
Hartman D.S. (1979) Ecology and behavior of the manatee (Trichechus manatus) in Florida. Lawrence, KS: American Society of Mammalogists Special Publication Series 5, 153 pp.

Heinsohn G.E. and Birch W.R. (1972) Foods and feeding habits of the dugong, Dugong dugong (Erxleben), in northern Queensland, Australia. Mammalia 36, 414-422.

Holechek J.L. and Vavra M. (1981) The effect of slide and frequency observation numbers on the precision of microhistological analysis. Journal of Range Management 34, 337-338.

Holechek J.L., Gross B., Dabo S.M. and Stephenson T. (1982a) Effects of sample preparation, growth stage, and observer on microhistological analysis of herbivore diets. Journal of Wildlife Management 46, 502504 .

Holechek J.L., Vavra M. and Pieper R.D. (1982b) Botanical composition determination of range herbivore diets: a review. Journal of Range Management 35, 309-315.

Hunter M.E., Mignucci-Giannoni A.A., Pause Tucker K.C., King T.L., Bonde R.K., Gray B.A. and McGuire P.M. (2012) Puerto Rico and Florida manatees represent genetically distinct groups. Conservation Genetics 13, 1623-1635.

Hurst L.A. and Beck C.A. (1988) Microhistological characteristics of selected aquatic plants of Florida with techniques for the study of manatee food habits. U.S. Fish and Wildlife Service Biological Report $88,1-145$.

Lanyon J.M. and Sanson G.D. (2006) Mechanical disruption of seagrass in the digestive tract of the dugong. Journal of Zoology 270, 277-289.

Larkin I.V., Fowler V.F. and Reep R.L. (2007) Digesta passage rates in the Florida manatee (Trichechus manatus latirostris). Zoo Biology 26, 503-515.

Ledder D.A. (1986) Food habits of the West Indian Manatee, Trichechus manatus latirostris, in South Florida. Thesis. University of Miami, Coral Gables, FL, 114 pp.

Lipkin Y. (1976) Food of the Red Sea dugong (Mammalia: Sirenia) from Sinai. Israel Journal of Zoology 24, 81-98.

Littler D.S., Littler M.M., Bucher K.E. and Norris J.N. (1989) Marine plants of the Caribbean, a field guide from Florida to Brazil. Washington, DC: Smithsonian Institution Press, $263 \mathrm{pp}$.

Littler M.M. and Littler D.S. (2008) The nature of crustose coralline algae and their interactions on reefs. Smithsonian Contributions to the Marine Sciences. No. 19, pp. 199-212.

Lomolino M.V. and Ewel K.C. (1984) Digestive efficiencies of the West Indian manatee (Trichechus manatus). Florida Scientist 47, 176-179.

Marsh H.D., Channells P.W., Heinsohn G.E. and Morrissey J. (1982) Analysis of stomach contents from dugongs from Queensland. Australian Wildlife Resources 9, 55-67.

Mignucci-Giannoni A.A. and Beck C.A. (1998) The diet of the manatee (Trichechus manatus) in Puerto Rico. Marine Mammal Science 14, 394-397.

Morales-Vela B., Olivera-Gomez D., Reynolds J.E. III and Rathbun G.B. (2000) Distribution and habitat use by manatees (Trichechus manatus manatus) in Belize and Chetumal Bay, Mexico. Biological Conservation 95, 67-75.

Navarro-Martinez Z.A., Alvarez-Aleman A. and Castelblanco-Martinez D.N. (2014) Diet components in three manatees in Cuba. Revista de Investigaciones Marinas 34, 1-11.

Odum W.E. and McIvor C.C. (1990) Mangroves. In Myers R.L. and Ewel J.J. (eds) Ecosystems of Florida. Orlando, FL: University of Central Florida Press, pp. 517-548. 
Orth R.J., Carruthers T.J.B., Dennison W.C., Duarte C.M. Fourquarean J.W., Heck K.L. Jr., Hughes A.R., Kendrick G.A., Kenworthy W.J., Olyarnik S., Short F.T., Waycott M. and Williams S.L. (2006) A global crisis for seagrass ecosystems. BioScience 56, 987-996.

O'Shea T.J. and Kochman H.I. (1990) Florida manatees: distribution, geographically referenced data sets, and ecological and behavioral aspects of habitat use. In Reynolds J.E. III and Haddad K.D. (eds) Report of the workshop on geographic information systems as an aid to managing habitat for West Indian manatees in Florida and Georgia. Volume 49. St Petersburg, FL: Florida Marine Research Publication, pp. 11-22.

O'Shea T.J. and Salisbury J.S. (1991) Belize - a last stronghold for the manatees in the Caribbean. Oryx 25, 156-164.

Owen M. (1975) An assessment of fecal analysis technique in waterfow feeding studies. Journal of Wildlife Management 39, 271-279.

Packard J.M. (1984) Impact of manatees Trichechus manatus on seagrass communities in eastern Florida. Acta Zoological Fennica 172, 21-22.

Packard J.M. and Wetterqvist O.F. (1986) Evaluation of manatee habitat systems on the northwestern Florida coast. Coastal Zone Management Journal 14, 279-310.

Parham-Garbutt A. (2015) The status of seagrass in the Placencia Lagoon. MS thesis. University of Belize, Belmopan, Belize, CA, $31 \mathrm{pp}$.

Perez I.J. (2005) Development of predictive models to explain the distribution of the West Indian manatee Trichechus manatus in tropical watercourses. Biological Conservation 125, 491-503.

Pinto da Silveria E.K. (1975) The management of Caribbean and Amazonian manatees, Trichechus m. manatus and T. inunguis, in captivity. International Zoo Yearbook 15, 223-226.

Powell J.A. Jr (1978) Evidence of carnivory in manatees (Trichechus manatus). Journal of Mammalogy 59, 442.

Preen A.R. (1995a) Diet of dugongs: are they omnivores? Journal of Mammalogy 76, 163-171.

Preen A.R. (1995b) Impacts of dugong foraging on seagrass habitats: observational and experimental evidence for cultivation grazing. Marine Ecology Progress Series 124, 201-213.

Quintana-Rizzo E. and Reynolds J.E. III (2007) Regional management plan for the West Indian manatee (Trichechus manatus). CEP Technical Report. Gosier, Guadeloupe, France: Caribbean Environment Programme, United Nations Environment Programme.

Rathbun G.B., Powell J.A. and Cruz G. (1983) Status of the West Indian manatee in Honduras. Biological Conservation 26, 301-308.

Reep R.L. and Bonde R.K. (2006) The Florida manatee: biology and conservation. Gainesville, FL: University Press of Florida, 224 pp.

Reynolds J.E. III, Szelistowski W.A. and Leon M.A. (1995) Status and conservation of manatees Trichechus manatus in Costa Rica Biological Conservation 71, 193-196.

SAS Institute Inc. (2013) SAS 9.1.3 help and documentation. Cary, NC: SAS Institute Inc.

Self-Sullivan C., Smith G.W., Packard J.M. and LaCommare K.S. (2003) Seasonal occurrence of male Antillean manatees (Trichechus manatus manatus) on the Belize Barrier Reef. Aquatic Mammals 29, 342-354

Severin K. (1955) Grazers of the sea. Natural History 64, 147-149.

Short F.T., Koch E.W., Creed J.C., Magalhaes K.M., Fernandez E. and Gaeckle J.L. (2006) SeagrassNet monitoring across the Americas: case studies of seagrass decline. Marine Ecology 27, 277-289.

Short F.T. and Wyllie-Echeverria S. (1996) Natural and human-induced disturbance of seagrasses. Environmental Conservation 23, 17-27.
Siegal-Willott J.L., Harr K., Hayek L.C., Scott K.C., Gerlach T., Sirois P., Reuter M., Crewz D.W. and Hill R.C. (2010) Proximate nutrient analyses of four species of submerged aquatic vegetation consumed by Florida manatee (Trichechus manatus latirostris) compared to romaine lettuce (Lactuca sativa var. longifolia). Journal of Zoo and Wildlife Medicine 41, 594-602.

Smith K.N. (1993) Manatee habitat and human-related threats to seagrass in Florida: a review. Tallahassee, FL: Florida Department of Environmental Protection, vi $+38 \mathrm{pp}$.

Waycott M., Duarte C.M., Carruthers T.J.B., Orth R.J., Dennison W.C., Olyarnik S., Calladine A., Fourquarean J.W., Heck K.L. Jr., Hughes A.R., Kendrick G.A., Kenworthy W.J., Short F.T. and Williams S.L. (2009) Accelerating loss of seagrasses across the globe threatens coastal ecosystems. PNAS 106, 12377-12381.

and

Wong A.W., Bonde R.K., Siegal-Willott J., Stamper M.A., Colee J., Powell J.A., Reid J.P., Deutsch C.J. and Harr K.E. (2012) Monitoring oral temperature, heart rate, and respiration rate of West Indian manatees (Trichechus manatus) during capture and handling in the field. Aquatic Mammals 38, 1-16.

\section{Correspondence should be addressed to:}

A.C. Allen

Halmos College of Natural Sciences and Oceanography, Nova Southeastern University, 8000 N. Ocean Drive, Dania Beach, FL 33004, USA email: aa1429@nova.edu

Appendix A. Per cent frequency: location.

\begin{tabular}{|c|c|c|}
\hline Location & $n$ & Per cent $(\%)$ \\
\hline \multicolumn{3}{|l|}{ Southern Lagoon } \\
\hline \multicolumn{3}{|l|}{ Seagrasses } \\
\hline Mixed rhizome & 100 & 90.09 \\
\hline Halodule wrightii & 85 & 76.58 \\
\hline Ruppia maritima & 49 & 44.14 \\
\hline Thalassia testudinum & 33 & 29.73 \\
\hline Syringodium filiforme & 4 & 3.60 \\
\hline Halophila sp. & 1 & 0.90 \\
\hline \multicolumn{3}{|l|}{ Vascular plants - other } \\
\hline Rhizophora mangle & 57 & 51.35 \\
\hline Unknown vascular plants & 2 & 1.80 \\
\hline \multicolumn{3}{|l|}{ Algae } \\
\hline Unknown filamentous algae & 38 & 34.23 \\
\hline Ulva sp. & 6 & 5.41 \\
\hline Chara sp. & 1 & 0.90 \\
\hline Lyngbia sp. & 1 & 0.90 \\
\hline \multicolumn{3}{|l|}{ Invertebrates } \\
\hline Sponge & 6 & 5.41 \\
\hline Unknown invertebrates & 2 & 1.80 \\
\hline \multicolumn{3}{|l|}{ Drowned Cayes } \\
\hline \multicolumn{3}{|l|}{ Seagrasses } \\
\hline Mixed rhizome & 29 & 90.63 \\
\hline Halodule wrightii & 29 & 90.63 \\
\hline Thalassia testudinum & 21 & 65.63 \\
\hline Ruppia maritima & 3 & $9 \cdot 38$ \\
\hline Halophila sp. & 1 & 3.13 \\
\hline \multicolumn{3}{|l|}{ Vascular plants - other } \\
\hline Rhizophora mangle & 19 & $59 \cdot 38$ \\
\hline
\end{tabular}


Appendix A. Continued

\begin{tabular}{lrc}
\hline Location & $\boldsymbol{n}$ & Per cent (\%) \\
\hline Algae & & \\
$\quad$ Unknown filamentous algae & 15 & 46.88 \\
Ulva sp. & 3 & 9.38 \\
Chara sp. & 3 & 9.38 \\
Lyngbia sp. & 1 & 3.13 \\
Unknown calcified algae & 1 & 3.13 \\
Invertebrates & & \\
Sponge & 13 & 40.63 \\
Diatoms & 5 & 15.63 \\
Unknown invertebrates & 2 & 6.25 \\
\hline
\end{tabular}

Appendix B. Belize manatee diet sample composite: location.

\begin{tabular}{lccccccc}
\hline Location & Mean & Min. & Max. & SD & Var & SE & CV \\
\hline $\begin{array}{l}\text { Southern Lagoon } \\
\quad \text { Seagrasses }\end{array}$ & 83.14 & 14.20 & 100 & 20.87 & 435.42 & 1.98 & 25.10 \\
$\quad \begin{array}{l}\text { Vascular plants } \\
\quad \text { other }\end{array}$ & 5.65 & 0 & 53.80 & 9.63 & 92.81 & 0.91 & 170.49 \\
$\quad$ & & & & & & & \\
$\quad$ Algae & 1.55 & 0 & 33.80 & 3.94 & 15.51 & 0.37 & 253.53 \\
$\quad$ Invertebrates & 0.43 & 0 & 13 & 1.99 & 3.96 & 0.19 & 460.16 \\
$\quad \begin{array}{l}\text { Drowned Cayes } \\
\quad \text { Seagrasses }\end{array}$ & 73.18 & 0 & 100 & 21.89 & 478.99 & 4 & 29.91 \\
$\quad$ Vascular plants & 11.11 & 0 & 84 & 18.02 & 324.84 & 3.29 & 162.18 \\
$\quad$ other & & & & & & & \\
$\quad$ Algae & 5.03 & 0 & 20.80 & 6.32 & 39.94 & 1.15 & 125.55 \\
$\quad$ Invertebrates & 6.05 & 0 & 33.20 & 9.38 & 87.99 & 1.71 & 155.13 \\
\hline
\end{tabular}

Appendix C. Per cent frequency: sex.

\begin{tabular}{|c|c|c|}
\hline Sex & $n$ & Per cent $(\%)$ \\
\hline \multicolumn{3}{|l|}{ Male } \\
\hline \multicolumn{3}{|l|}{ Seagrasses } \\
\hline Mixed rhizome & 58 & 89.23 \\
\hline Halodule wrightii & 52 & 80 \\
\hline Ruppia maritima & 26 & 40 \\
\hline Thalassia testudinum & 26 & 40 \\
\hline Halophila sp. & 2 & 3.08 \\
\hline Syringodium filiforme & 1 & 1.54 \\
\hline \multicolumn{3}{|l|}{ Vascular plants - other } \\
\hline Rhizophora mangle & 29 & 44.62 \\
\hline Unknown vascular plants & 2 & 3.08 \\
\hline \multicolumn{3}{|l|}{ Alga } \\
\hline Unknown filamentous algae & 24 & 36.92 \\
\hline Ulva sp. & 4 & 6.15 \\
\hline Chara sp. & 2 & 3.08 \\
\hline \multicolumn{3}{|l|}{ Invertebrates } \\
\hline Sponge & 6 & 9.23 \\
\hline Diatoms & 3 & 4.62 \\
\hline \multicolumn{3}{|l|}{ Female } \\
\hline \multicolumn{3}{|l|}{ Seagrasses } \\
\hline Mixed rhizome & 69 & 90.79 \\
\hline Halodule wrightii & 60 & 78.95 \\
\hline Thalassia testudinum & 27 & $35 \cdot 53$ \\
\hline Ruppia maritima & 26 & 34.21 \\
\hline Syringodium filiforme & 3 & 3.95 \\
\hline
\end{tabular}

Continued
Appendix C. Continued

\begin{tabular}{lrc}
\hline Sex & $n$ & Per cent (\%) \\
\hline Vascular plants - other & & \\
$\quad$ Rhizophora mangle & 47 & 61.84 \\
Algae & 28 & 36.84 \\
$\quad$ Unknown filamentous algae & 5 & 6.58 \\
Ulva sp. & 2 & 2.63 \\
Chara sp. & 2 & 2.63 \\
Lyngbia sp. & 1 & 1.32 \\
Unknown calcified algae & & \\
Invertebrates & 13 & 17.11 \\
$\quad$ Sponge & 4 & 5.26 \\
$\quad$ Unknown invertebrates & 2 & 2.63 \\
$\quad$ Diatoms & & \\
\hline
\end{tabular}

Appendix D. Belize manatee diet sample composite: sex

\begin{tabular}{lrllllll}
\hline Sex & Mean & Min. & Max. & SD & Var & SE & CV \\
\hline Male & & & & & & & \\
$\quad$ Seagrasses & 83.41 & 27.40 & 100 & 19.05 & 363.09 & 2.36 & 22.84 \\
$\quad$ Vascular plants & 5.02 & 0 & 39.60 & 8.22 & 67.64 & 1.02 & 163.98 \\
$\quad$ other & & & & & & & \\
$\quad$ Algae & 2.06 & 0 & 20.80 & 3.93 & 15.47 & 0.49 & 191.08 \\
$\quad$ Invertebrates & 1.30 & 0 & 33.20 & 5.27 & 27.81 & 0.65 & 404.22 \\
Female & & & & & & & \\
$\quad$ Seagrasses & 78.97 & 0 & 100 & 23.15 & 536.02 & 2.66 & 29.32 \\
$\quad$ Vascular plants & 8.35 & 0 & 84 & 14.43 & 208.21 & 1.66 & 172.81 \\
$\quad$ other & & & & & & & \\
$\quad$ Algae & 2.49 & 0 & 33.80 & 5.36 & 28.71 & 0.61 & 214.77 \\
$\quad$ Invertebrates & 1.90 & 0 & 29.20 & 5.09 & 25.86 & 0.58 & 267.27 \\
\hline
\end{tabular}

Appendix E. Per cent frequency: size classification.

\begin{tabular}{lcc}
\hline Size class & $n$ & Per cent (\%) \\
\hline Calf & & \\
$\quad$ Seagrasses & & \\
$\quad$ Halodule wrightii & 11 & 91.67 \\
$\quad$ Mixed rhizome & 10 & 83.33 \\
$\quad$ Thalassia testudinum & 4 & 33.33 \\
$\quad$ Ruppia maritima & 4 & 33.33 \\
Vascular plants - other & & \\
$\quad$ Rhizophora mangle & 5 & 41.67 \\
Algae & & \\
$\quad$ Unknown filamentous algae & 3 & 25 \\
$\quad$ Lyngbia sp. & 1 & 8.33 \\
$\quad$ Unknown calcified algae & 1 & 8.33 \\
Invertebrates & & \\
$\quad$ Sponge & 2 & 16.67 \\
$\quad$ Unknown invertebrates & 1 & 8.33 \\
Subadult & & \\
Seagrasses & & \\
$\quad$ Mixed rhizome & 34 & 89.47 \\
$\quad$ Halodule wrightii & 28 & 73.68 \\
$\quad$ Thalassia testudinum & 8 & 21.05 \\
$\quad$ Syringodium filiforme & 3 & 7.89 \\
$\quad$ Halophila sp. & 1 & 2.63 \\
\hline
\end{tabular}

Continued 
Appendix E. Continued

\begin{tabular}{|c|c|c|}
\hline Size class & $n$ & Per cent $(\%)$ \\
\hline \multicolumn{3}{|l|}{ Vascular plants - other } \\
\hline Rhizophora mangle & 24 & 63.16 \\
\hline Unknown vascular plants & 1 & 2.63 \\
\hline \multicolumn{3}{|l|}{ Algae } \\
\hline Unknown filamentous algae & 8 & 21.05 \\
\hline Ulva sp. & 4 & 10.53 \\
\hline Chara sp. & 2 & 5.26 \\
\hline \multicolumn{3}{|l|}{ Invertebrates } \\
\hline Unknown invertebrates & 2 & 5.26 \\
\hline \multicolumn{3}{|l|}{ Adult } \\
\hline \multicolumn{3}{|l|}{ Seagrasses } \\
\hline Mixed rhizome & 84 & 92.31 \\
\hline Halodule wrightii & 74 & 81.32 \\
\hline Thalassia testudinum & 41 & 45.05 \\
\hline Ruppia maritima & 29 & 31.87 \\
\hline Halophila sp. & 1 & 1.10 \\
\hline Syringodium filiforme & 1 & 1.10 \\
\hline \multicolumn{3}{|l|}{ Vascular plants - other } \\
\hline Rhizophora mangle & 47 & 51.65 \\
\hline Unknown vascular plants & 1 & 1.10 \\
\hline \multicolumn{3}{|l|}{ Algae } \\
\hline Unknown filamentous algae & 41 & 45.05 \\
\hline Ulva sp. & 5 & 5.49 \\
\hline Chara sp. & 2 & 2.20 \\
\hline Lyngbia sp. & 1 & 1.10 \\
\hline \multicolumn{3}{|l|}{ Invertebrates } \\
\hline Sponge & 14 & $15 \cdot 38$ \\
\hline Diatoms & 5 & 5.49 \\
\hline Unknown invertebrates & 1 & 1.10 \\
\hline
\end{tabular}

Appendix F. Belize manatee diet sample composite: size classification.

\begin{tabular}{lcccrrrr}
\hline Size class & Mean & Min. & Max. & SD & Var & SE & CV \\
\hline Calf & & & & & & & \\
$\quad$ Seagrasses & 85.02 & 47.40 & 100 & 17.86 & 318.85 & 5.15 & 21 \\
$\quad$ Vascular plants & 3.25 & 0 & 15.20 & 5.45 & 29.65 & 1.57 & 167.55 \\
$\quad$ - other & & & & & & & \\
$\quad$ Algae & 2.20 & 0 & 18.40 & 5.32 & 28.31 & 1.54 & 241.86 \\
$\quad$ Invertebrates & 1.10 & 0 & 5.60 & 2.10 & 4.42 & 0.61 & 191.09 \\
Subadult & & & & & & & \\
$\quad$ Seagrasses & 79.26 & 0 & 100 & 25.24 & 637.20 & 4.09 & 31.85 \\
$\quad$ Vascular plants & 10.91 & 0 & 84 & 18.45 & 340.31 & 2.99 & 169.08 \\
$\quad$ other & & & & & & & \\
$\quad$ Algae & 1.07 & 0 & 12.60 & 2.59 & 6.70 & 0.42 & 241.14 \\
$\quad$ Invertebrates & 1.10 & 0 & 16.20 & 3.73 & 13.94 & 0.61 & 339.38 \\
Adult & & & & & & & \\
$\quad$ Seagrasses & 81.23 & 23.40 & 100 & 20.20 & 408.14 & 2.12 & 24.87 \\
$\quad$ Vascular plants & 5.57 & 0 & 53.80 & 8.49 & 72.06 & 0.89 & 152.37 \\
$\quad$ other & & & & & & & \\
$\quad$ Algae & 2.82 & 0 & 33.80 & 5.28 & 27.88 & 0.55 & 187.54 \\
$\quad$ Invertebrates & 1.92 & 0 & 33.20 & 5.91 & 34.96 & 0.62 & 308.50 \\
\hline
\end{tabular}

Appendix G. Per cent frequency: season.

\begin{tabular}{|c|c|c|}
\hline Season & $n$ & Per cent $(\%)$ \\
\hline \multicolumn{3}{|l|}{ Wet } \\
\hline \multicolumn{3}{|l|}{ Seagrasses } \\
\hline Mixed rhizome & 82 & 92.13 \\
\hline Halodule wrightii & 75 & 84.27 \\
\hline Thalassia testudinum & 39 & 43.82 \\
\hline Ruppia maritima & 33 & 37.08 \\
\hline Syringodium filiforme & 1 & 1.12 \\
\hline \multicolumn{3}{|l|}{ Vascular plants - other } \\
\hline Rhizophora mangle & 55 & 61.80 \\
\hline Unknown vascular plants & 2 & 2.25 \\
\hline \multicolumn{3}{|l|}{ Algae } \\
\hline Unknown filamentous algae & 29 & 32.58 \\
\hline Ulva sp. & 7 & 7.87 \\
\hline Chara sp. & 3 & $3 \cdot 37$ \\
\hline \multicolumn{3}{|l|}{ Invertebrates } \\
\hline Sponge & 12 & 13.48 \\
\hline Diatoms & 3 & $3 \cdot 37$ \\
\hline Unknown invertebrates & 2 & 2.25 \\
\hline \multicolumn{3}{|l|}{ Dry } \\
\hline \multicolumn{3}{|l|}{ Seagrasses } \\
\hline Mixed rhizome & 47 & 90.38 \\
\hline Halodule wrightii & 39 & 75 \\
\hline Ruppia maritima & 19 & 36.54 \\
\hline Thalassia testudinum & 15 & 28.85 \\
\hline Syringodium filiforme & 3 & 5.77 \\
\hline Halophila sp. & 2 & 3.85 \\
\hline \multicolumn{3}{|l|}{ Vascular plants - other } \\
\hline Rhizophora mangle & 21 & 40.38 \\
\hline \multicolumn{3}{|l|}{ Algae } \\
\hline Unknown filamentous algae & 24 & 46.15 \\
\hline Lyngbia sp. & 2 & 3.85 \\
\hline Ulva sp. & 2 & 3.85 \\
\hline Chara sp. & 1 & 1.92 \\
\hline Unknown calcified algae & 1 & 1.92 \\
\hline \multicolumn{3}{|l|}{ Invertebrates } \\
\hline Sponge & 7 & 13.46 \\
\hline Diatoms & 2 & 3.85 \\
\hline Unknown invertebrates & 2 & 3.85 \\
\hline
\end{tabular}

Appendix H. Belize manatee diet sample composite: season.

\begin{tabular}{lccccccc}
\hline Season & Mean & Min. & Max. & SD & Var & SE & CV \\
\hline Wet & & & & & & & \\
$\quad$ Seagrasses & 79.86 & 0 & 100 & 22.04 & 485.93 & 2.34 & 27.60 \\
$\quad$ Vascular plants & 8.53 & 0 & 84 & 14.22 & 202.30 & 1.51 & 166.74 \\
$\quad \quad$ other & & & & & & & \\
$\quad$ Algae & 2.11 & 0 & 20.80 & 3.99 & 15.93 & 0.42 & 188.73 \\
$\quad$ Invertebrates & 1.71 & 0 & 33.20 & 5.55 & 30.83 & 0.59 & 323.86 \\
$\quad \begin{array}{l}\text { Dry } \\
\quad \text { Seagrasses }\end{array}$ & 83 & 27.40 & 100 & 20.31 & 412.64 & 2.82 & 24.47 \\
$\quad$ Vascular plants & 3.87 & 0 & 18.20 & 5.97 & 35.67 & 0.83 & 154.21 \\
$\quad \quad$ other & & & & & & & \\
$\quad$ Algae & 2.60 & 0 & 33.80 & 5.84 & 34.13 & 0.81 & 224.69 \\
$\quad$ Invertebrates & 1.48 & 0 & 21.60 & 4.46 & 19.93 & 0.62 & 302.28 \\
\hline
\end{tabular}

